\title{
NOTES ON AUTHORS
}

Julie Evans was born in Australia and obtained degrees in politics, women's studies and history from La Trobe University and the University of Melbourne, where she is Australian Research Council postdoctoral fellow in the Department of History. Her teaching and research interests centre on nineteenth-century British colonialism and she has published work on Australia, South Africa and the Caribbean. She is currently completing a book the methodological approach of which casts new light on the career of Colonial Governor Edward Eyre. Her postdoctoral research focuses on the rule of law in the colonial encounter.

Patricia Grimshaw was born and grew up in New Zealand at a time when the country considered itself the model of a society in which Indigenous and White people lived together harmoniously. She obtained degrees in history and English from the University of Auckland and a doctorate from the University of Melbourne, where she currently holds the Max Crawford Chair of History. She teaches and researches in the areas of Australian, Pacific and western United States' history, with particular interests in the comparative histories of gender, colonialism and 'race'. She is the author of a number of studies, including Women's Suffrage in New Zealand (rev.edn, 1987) and Paths of Duty: Missionary Wives in Nineteenth-Century Hawai'i (1989), co-author of Creating a Nation (1994) and co-editor of Women's Rights and Human Rights: International Historical Perspectives (2001).

David Philips was born and grew up in South Africa under the apartheid regime. He obtained degrees in history and English from the University of the Witwatersrand and Oxford University before coming to the Department of History at the University of Melbourne. He has taught courses on modern British social history, South African history, colonial Australian history, and comparative colonial history - from the last of which the idea for this book arose. He has published extensively on the history of crime, law and policing in nineteenth-century England and colonial Australia, and a little on modern South Africa in the apartheid period.

Shurlee Swain was born in Australia and obtained degrees in history and social work from the University of Melbourne. She is an associate professor and reader in history at the Australian Catholic University and a senior research associate in the Department of History at the University of Melbourne. Her research and teaching have encompassed Australian social history, the history of women and children, and comparative colonial history. Her most recent monographs are Single Mothers and Their Children (1995) and Confronting Cruelty (2001). 